\title{
A Survey of Computer Education Courses in Canadian Faculties of Education
}

\author{
BETTY COLLIS and WALTER MUIR*
}

\begin{abstract}
Paralleling the rapid entry of microcomputers into the elementary and secondary schools of Canada has been the development of a broad range of credit courses, within faculties of education, designed to train teachers in the application of computer technology to teaching and learning. This survey of computer education courses and programs in Canadian faculties of education was conducted in February 1985, in order to provide baseline data for a continuing review of the nature and impact of these courses. The results of the survey confirm that the response of education faculties has been quite dramatic, with a total of 260 undergraduate and 85 graduate courses now being offered. However, categorization of the courses shows considerable diversity in both content and sequence. Further, there is no consistency among the various institutions in their requirements for computer-related experiences prior to teacher certification.
\end{abstract}

\section{RÉSUMÉ}

En réponse à l' introduction rapide du micro-ordinateur dans les écoles primaires et secondaires du Canada, les facultés universitaires d'éducation ont développé un grand nombre de cours conçus spécialement pour entraîner les professeurs à utiliser l'informatique au niveau pédagogique. Le sondage de cours et de programmes concernant l'informatique offerts par les facultés canadiennes d'éducation effectué en février 1985, a eupour but de procurer un data de base qui permettra de vérifier de façon régulière la nature et l'impact de ces cours. Les résultats du sondage confirment que la réaction des facultés d'éducation a été des plus vives. Nous avons, en effet, un total de 260 cours pour étudiants sous-gradués et de 85 cours pour étudiants gradués offerts aujourd' hui dans nos universités. La catégorisation de ces cours révèle toutefois une diversité considérable dans les domaines du contenu et du développement séquentiel. De plus, il existe un écart considérable parmi les diverses institutions quant aux demandes requises en matière d'informatique avant d'accorder aux enseignants leur diplôme.

* Betty Collis, Ph.D., and Walter Muir, Ph.D., are Assistant and Associate Professors respectively in the Department of Psychological Foundations, Faculty of Education, University of Victoria, P.O. Box 1700, Victoria, British Columbia, V8W 2Y2. Correspondence can be sent to either author at this address. 
With the use of microcomputers in Canadian schools now well established, the extent to which Canadian faculties of education have responded to the growing demand for courses that support the use of computers in schools is of interest. Proctor, Schwier, and Brown (1984) provided initial information by publishing calendar entries of specific computer education courses offered by 18 Canadian universities and colleges, and plan to publish a 1985 update involving more institutions. This article, in contrast, attempts to summarize and interpret the results of a nation-wide survey identifying credit courses relating to computers in education offered during 1984-85 by examining the following questions:

1. How many undergraduate credit courses directed to computers in education at Canadian universities are currently offered, and how can they be described?

2. How many graduate level credit courses directed toward computers in education are currently offered, and how can they be described?

3. Is there a consensus regarding content and sequence with respect to these courses?

4. Which departments within Canadian faculties of education offer these credit courses in computer education?

5. To what extent are preservice teachers in Canada required to take some computer training before certification?

6. Can educators with differing computer-related interests and responsibilities find appropriate course offerings in Canadian universities?

\section{METHOD}

\section{Respondents}

A survey was conducted in February 1985, in which the Dean of every Canadian faculty or department of education listed in the CEA Administrators' Handbook (1984) was sent a questionnaire. Forty-three of the 49 institutions $(88 \%)$ responded to the survey.

\section{Instrument}

The survey consisted of a two-page questionnaire. Institutions were asked to list all current credit courses relating to computers in education, and to enclose course descriptions or syllabi. Many institutions returned the calendar entries describing the pertinent courses. In addition, the survey asked various questions about organizational arrangements surrounding computer education courses and inquired about the nature of required computer training for preservice teachers.

\section{RESULTS}

\section{Undergráduate}

Table 1 summarizes the number of undergraduate credit courses offered at Canadian faculties of education as of February 1985. It can be seen that 8 of the universities offer an extensive number of undergraduate courses in computer education. These universities are: McGill University (14), University of Ottawa/ 


\section{Table 1}

Undergraduate Credit Courses in Computer Education at Canadian Universities as of February, 1985

$\begin{array}{rr}\text { N/A } & 3 \\ \text { None } & 3 \\ 1 & 6 \\ 3 & 6 \\ 4 & 5 \\ 5 & 4 \\ 6 & 4 \\ 7 & 1 \\ 14 & 2 \\ 17-21 & 4 \\ 29-35 & 2\end{array}$

Total courses $=260$

Note. Based on 43 respondents from 49 institutions.

Université d'Ottawa (14 in English, with 10 additional French language courses whose content would seem to parallel the English language courses), Université Laval (17), Université du Québec à Trois-Rivières (17), Université du Québec à Chicoutimi (19), Université du Québec à Rimouski (21), Université de Sherbrooke (29), and Université du Québec à Montréal (35). The mean number of undergraduate courses from the responding institutions is 6.5 ; the median is 4 . However, a bimodal situation is clearly indicated with 8 institutions, of which 7 are French-speaking, forming one group with an average of 20.75 undergraduate credit courses each, and the remaining 34 having an average of approximately 3 undergraduate credit courses each. (The Ontario Institute for Studies in Education, OISE, does not offer undergraduate courses.) 
A. General, Introductory

B. Second-level, General Course

C. Curriculum Applications:

General

Specific Subject

D. Curriculum and Instruction for

Computer Science Teachers

E. Programming

F. Software Evaluation, Design and Authoring

G. Computers and Specific Groups of Users

H. Specific Types of Uses of

Computers

I. Other

Each of the courses was categorized as best matching one of nine descriptions. These descriptions and the number of undergraduate credit courses associated with each are given in Table 2.

Group A, general introductory courses, are given at 33 of the institutions. In 11 institutions, more than one course seems to be best described in this category. Group A courses vary in their content but typically include a survey of practical applications of computers in education, including administrative uses; some introduction to applications software, such as word processing; some instruction 
about the computer itself; and experiences in the evaluation of educational software. Group A courses include those which prepare candidates for the Ontario Ministry of Education qualification, Computers in the Classroom, Part I.

Group B, second-level general courses, typically include a more intensive look at the same categories of topics covered in introductory courses. Programming of a simple instructional program is often a component of Group B courses. Group B includes courses which prepare candidates for the Ontario Ministry of Education qualification, Computers in the Classroom, Part II.

Group C consists of courses that focus on the use of the computer for instruction in specific curriculum areas. Thirteen of these address curriculum in general and the rest relate to specific areas, including mathematics (11 courses), French language instruction (9) and business education (4).

Group D includes courses aimed specifically at content and methodology appropriate for secondary level computer science instruction.

Group E consists of courses focussing on programming; 11 of the 31 courses in this group are based on LOGO, 3 specifically involve BASIC programming, and only 1 focusses on Pascal.

Group F, which includes courses involving the design and construction of educational software, presumably involves some programming instruction as well.

Group $\mathrm{G}$ includes courses focussed on the use of computers by specific groups of users including administrators (4 courses), special education students (2), and primary and pre-school students (4). Also in this group are courses that prepare teachers to be computer-resource persons in their own educational communities (3), including courses which prepare candidates for the Ontario Ministry of Education qualification, Computers in the Classroom, Part III (specialist).

Group $\mathrm{H}$ courses focus on specific uses of computers in educational settings, such as word processing (4), simulations (6), student management (5), use of databases (2) and telecommunications (5). Two courses described as focussing on artificial intelligence are also in this group.

The last category (Group I) includes a variety of courses from the 8 institutions which offer the most extensive array of courses. These include topics such as Computers and Society, Computers at School and Home, and the Use of Computers for Testing and Diagnosis.

The considerable variety of undergraduate credit courses, taken together, provides a thorough representation of this new area of study, Computers in Education. While a consensus about the scope of the area is emerging, is there agreement yet as to a sequence of courses? After an introductory course, what next? In the 26 universities indicating between 2 and 7 undergraduate credit courses, no clear pattern has emerged. Those that offer 2 credit courses offer 4 types of courses (from Group B, C, D, and E) as their second courses. Those that offer 3 courses offer introductory and non-introductory general courses, but again show no consensus for the remaining courses, with courses from Groups B, D, E, and F. Courses in the methodology of teaching secondary computer science are only available in 12 of the 42 undergraduate institutions. 
Number of Graduate Courses in Computer Education

1

2

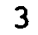

4

5

6

7

9

10

24

Total 85

\section{9}

1

3

1

1

1

1

1

1

1

20

\section{Graduate}

Table 3 shows that 20 institutions offer graduate courses in computers in education and that a total of 85 courses were described. OISE, with 24 of the courses, offers the most extensive selection. The University of Western Ontario offers 10 graduate courses, the University of Calgary 9, and Concordia University 7. Nine of the 20 institutions offering graduate courses offer only a single course and seven of these can be classified as Group A, general introductory courses. Table 4 shows descriptions of the 85 graduate courses, using the categories defined in Table 2.

Course offerings at the graduate level are similar to those for undergraduate in both scope and sequence. This is particularly the case with respect to Group A general courses. In addition, however, graduate offerings include two researchoriented categories. Examples of these research-related courses include "Topics in Educational Information" (Concordia), "Simulation Models of Cognition and Learning," "Intelligent Computer Systems in Instruction and Learning," "Decision Support Systems in Education," and "Programming Applications in the Ontario Curriculum" (OISE), "Computer Applications for Rehabilitation" (Cal- 
Table 4

Categories of Graduate credit Courses

Category
Number of Courses
A. General, Introductory 20

B. Second-level, General

C. Curriculum Applications

D. Computer Science Instruction

E. Programming

F. Software Evaluation and Design

G. Computers and Specific Groups of Users

H. Specific Uses of Computers

I. Research-related Courses

J. Research Project Courses

K. Other

\section{4}

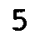

4

3

7

4

Total 85

gary), and "Advanced Computer Applications in Educational Psychology" (Manitoba).

Finally, with regard to graduate degree programs, five of the responding institutions indicated a specialization area in some aspect of computer education at the master's level. The five are: Concordia, Manitoba, OISE, Simon Fraser, and Victoria. At the Ph.D. level, only Concordia and OISE indicated specific programs.

\section{Departmental Affiliation of Computers in Education Courses}

Have computers in education courses found a natural academic base? Are they most appropriately a subsection of educational technology departments, of educational psychology, or of curriculum studies, or does the area stand alone as a discipline? Only 19 of those reporting indicated a specific department to which 
Table 5

Departmental Affiliations of Computers in Education Courses

Area

Number of Institutions

Educational Psychology

4

Curriculum:

Mathematics and Science

Business Education

Mathematics Education

Educational Technology

Measurement, Evaluation and

Computer Applications

Curriculum

Teacher Education

Elementary Education

Département de Pédagogie

Business and Computer Studies

Computer studies

Note. Some institutions offer courses in more than one department.

computer education courses were attached. Within these 19, there appeared to be little consistency in departmental designations among institutions. Table 5 summarizes these departmental affiliations. This lack of consistency may reflect the recent entry of computer education courses into academic calendars, or perhaps more significantly, the lack of maturity of the area as a distinct discipline. 


\section{Teacher Training Requirements in Computer Education}

Respondents were asked to indicate if "some computer experience is required as part of your institution's teacher training program." The question was not applicable for OISE since it has no undergraduate program and another institution's response was not clear. Of the remaining 41 institutions, 16 indicated a computer experience requirement, while 25 indicated no requirement for computer-based experience as part of teacher training. Of those who indicated no experience was required, 3 noted that it was either strongly recommended or was soon to become mandatory. Of the 16 which require some computer experience as part of teacher training, only 2 stipulate a full "computers in education" course (McGill and Nova Scotia Teachers College). At the other institutions, the required computer experiences are presented as a component of a variety of methods or curriculum courses, or as part of required media courses. Similar to the situation with respect to departmental affiliations for computers in education courses, there is as yet no pattern, either of scope or focus, for the provision of training in computer applications for preservice teachers in Canada.

\section{DISCUSSION}

The responses show that the study of the use of computers in education has been accepted by virtually every faculty of education as appropriate for formal course instruction. They also show that the growth in the number of courses has not yet been matched by a cohesiveness of opinion with regard to the nature of computer education. This reflects the lack of consensus in the education profession, generally, with regard to questions such as the following:

1. Is computer education a new discipline or a methodological adjunct to existing areas of study?

2. Given the newness of the area, and the lack of consensus regarding it, what background experiences and qualifications do the instructors of the 345 credit courses share?

3. For which teachers are computer education courses appropriate or even necessary?

4. Should teachers receive some of their basic computer-related coursework in computer science departments rather than in faculties of education?

5. To what extent does the content of general introductory computer education courses duplicate that of non-credit inservice experiences already available to teachers through school district or professional association activity?

Since the purpose of this survey was to describe the current state of computer education in Canadian universities, questions such as these remain to be answered. However, the diversity of current course offerings indicates a need for greater communication among those involved, so that a consensus regarding the range of concepts and skills appropriate to computer education can emerge.

As a contribution to such a consensus, the survey data do allow an evaluation of the existing computer education courses in Canadian faculties of education relative 
to the needs of various categories of educational users of computers. A variety of different categorizations has appeared (Anderson, 1985; Baird, 1984; Moore, 1984; Sleeman, 1984). From these, and other sources, four general categories of computer-using educators can be described:

1. Classroom teachers (non-computer science)

2. Computer science teachers

3. Coordinators or computer resource teachers (this category includes school administrators involved in computer-related policy and direction)

4. Specialists in the design and development of educational software.

What types of training do these four categories of computer-using educators require and how well do Canadian universities provide these different sets of experiences? We suggest that the classroom teacher group needs at least a general introduction course and also would benefit from courses emphasizing curriculum applications of computers and the evaluation of educational software. Secondary school computer science teachers could use at least two courses; one in methodology of teaching computing and another in programming and computer science concepts (although the latter may be more appropriately offered through departments of computer science rather than within education faculties). Computer resource persons should, as a bare minimum, have at least one general course, but should also have a course in curriculum applications, another in software evaluation, and preferably some training in computer-based administration or student management strategies. Finally, software design specialists would benefit from a general course, a programming course, a curriculum application course, a software evaluation course and a course centred on design and production of instructional software.

Because most general courses appear to be broadly based, it is possible that educators in the classroom teacher and the computer resource teacher categories may be receiving a reasonable preparation at universities which offer a single course. However, teachers of senior secondary computer science and educators interested in software design and production are less likely to have their needs met by the majority of Canadian faculties of education.

For example, only 13 of the 43 institutions responding to the survey offer specific courses in methodology and content pertinent to secondary computer science. Fourteen offer specific training in the design and/or authoring of educational software. However, the overall situation is that while the majority of institutions attempt to provide one or two general and perhaps one or two specialized courses, only a few offer a sequence appropriate to the needs of even one of the four groups of computer-using educators. Only those 9 or 10 institutions with extensive programs have the depth to offer appropriate training to a variety of users.

Apparently, most institutions either cannot or have not chosen to become highly committed to computer education programs. For many institutions, providing more than a few courses may not be a realistic goal. If only a few computer education courses can be offered what should this minimum subset of courses be? 
Here is where some consensus would be especially valuable. As a suggestion, one such subset might include: a general introductory course at the undergraduate level; another general course at the graduate level which would be clearly different from the undergraduate course in that it would be research-oriented and consider the implications of the educational use of computers rather than the practical management of the machine in a classroom setting; a methods course for secondary level computer science teachers; and a course in some aspect of instructional programming. Only three Canadian universities seem to include this particular subset within their computers in education offerings.

\section{CONCLUSION}

This survey of Canadian faculties and departments of education in February 1985, shows that virtually all offer computers in education courses. Eight universities offer extensive undergraduate programs while OISE dominates the field in number and range of graduate offerings. An analysis of the scope and sequence of information and applications focussed upon by these courses shows little consistency from institution to institution. Some computer training is required of , student teachers in $38 \%$ of the responding institutions, but this training varies in content and foundation in the same ways as do the credit courses. A consensus regarding focus and sequence is clearly called for; computer education faculty members from across Canada would profit from an opportunity to meet and discuss their various perspectives and experiences before the number of credit courses increases.

\section{REFERENCES}

Anderson, E. L. (1985, April). Graduate microcomputer instruction: Another perspective. Paper presented at the meeting of AEDS/ECOO, Toronto.

Baird, W. E. (1984). A road atlas for computer literacy and teacher training. The Computing Teacher, 12(3), 11-16.

Moore, M. L. (1984). Preparing computer-using educators. The Computing Teacher, 12(2), 48-52.

Proctor, L., Schwier, R., \& Brown, B. (1984). Courses in microcomptiters in education in Canadian universities. Special supplement. Canadian Journal of Educational Communication, 13(3).

Sleeman, D. (1984). Computers and education: The missing link. Occasional Report \#005. Technology Panel, Study of Stanford and the Schools. Stanford University. 